\title{
Compositional variations of active autotrophic bacteria in paddy soils with elevated $\mathrm{CO}_{2}$ and temperature
}

\author{
Chen Zhu', Ning Ling ${ }^{1, *}$, Ling $\mathrm{Li}^{1}$, Xiaoyu $\mathrm{Liu}^{2}$, Michaela A. Dippold ${ }^{3}$, Xuhui Zhang ${ }^{2}$, Shiwei Guo ${ }^{1}$, \\ Yakov Kuzyakov ${ }^{3,4,5}$, Qirong Shen ${ }^{1}$ \\ 1 Jiangsu Provincial Key Lab for Organic Solid Waste Utilization, Nanjing Agricultural University, Nanjing 210095, China \\ 2 College of Resources and Environmental Sciences, Nanjing Agricultural University, Nanjing 210095, China \\ 3 Department of Soil Science of Temperate Ecosystems, Department of Agricultural Soil Science, University of Goettingen, 37073 Göttingen, \\ Germany \\ 4 Institute of Environmental Sciences, Kazan Federal University, 420049 Kazan, Russia \\ 5 Agro-Technology Institute, RUDN University, 117198 Moscow, Russia
}

A RTICLE INFO

\section{Article history:}

Received March 11, 2020

Revised April 23, 2020

Accepted May 20, 2020

\section{Keywords:}

Climate change

Paddy soil

Ammonia-oxidizing bacteria

Nitrite-oxidizing bacteria

Stable isotope probing

Microbial community

\begin{abstract}
A B S T R A C T
Global warming is an increasingly serious ecological problem, we examined how the active autotrophic microbes in paddy soils respond to the elevated $\mathrm{CO}_{2}$ and temperature. Here we employed stable isotope probing (SIP) to label the active bacteria using the soil samples from a fully factorial Simulated Climate Change (SCC) field experiment where soils were exposed to ambient $\mathrm{CO}_{2}$ and temperature, elevated temperature, elevated $\mathrm{CO}_{2}$, and both elevated $\mathrm{CO}_{2}$ and temperature. Around $28.9 \%$ of active OTUs belonged to ammonia-oxidizing bacteria $(\mathrm{AOB})$ and nitrite-oxidizing bacteria (NOB). Nitrosospira taxa was dominant in all soils and $80.4 \%$ of carbon-fixing bacteria under elevated temperature were classified as Nitrosomonas nitrosa. While no labeled NOBs were detected when temperature or $\mathrm{CO}_{2}$ were elevated independently, diverse NOBs were detected in the ambient conditions. We found that elevated $\mathrm{CO}_{2}$ and temperature had contrasting effects on microbial community composition, while relatively small changes were observed when $\mathrm{CO}_{2}$ and temperature were elevated simultaneously. Summarily these results suggest that carbon-fixing bacteria can respond positively to elevated $\mathrm{CO}_{2}$ concentrations, but when it's accompanied with increase in the temperature this positive response could be weakened. Multiple abiotic factors thus need to be considered when predicting how microbial communities will respond to multiple climatic factors.
\end{abstract}

(c) Higher Education Press 2020

\section{Introduction}

Climate model projections indicate that the atmospheric carbon dioxide $\left(\mathrm{CO}_{2}\right)$ concentration may double and the global average temperature will rise by another $1.1-6.4^{\circ} \mathrm{C}$

\footnotetext{
* Corresponding author

E-mail address: nling@njau.edu.cn (N. Ling)
}

during the 21st century (Stocker et al., 2013). The properties and functions of terrestrial ecosystems would be profoundly altered under this unprecedented global climate change (Rosenzweig et al., 2007) and will lead to massive losses of habitat and organism diversity (Wetzel et al., 2012; Courchamp et al., 2014). Therefore, it is urgently necessary to relieve $\mathrm{CO}_{2}$ concentration elevation by as many measures as possible. Terrestrial ecosystems are the dominant sink for 
global $\mathrm{CO}_{2}$ emissions and are of significant interest because of their potential to alleviate atmospheric $\mathrm{CO}_{2}$ levels (Lal, 2008). Compared to soils of upland crops, paddy soils tend to accumulate more soil organic carbon (SOC) (Sahrawat, 2004; Kögel-Knabner et al., 2010; Sun et al., 2015). This is mainly caused by the limited availability of oxygen under flooded conditions, which slows down decomposition of organic inputs, especially lignin and other phenolic compounds (Olk and Senesi, 2000; Gao et al., 2016).

Paddy soils cover a total area of approximately 165 million ha globally (Ge et al., 2015). 26\% of cropland in China is used for rice cultivation, which is significant $C$ sink, potentially sequestering up to $0.7 \mathrm{Pg} \mathrm{C}$ annually (Pan et al., 2004). Paddy ecosystems, especially in China, are thus critically important for $\mathrm{CO}_{2}$ fixation. The role of plants in $\mathrm{C}$ fixation and belowground input is well known. Plant photosynthesis and $\mathrm{C}$ allocation belowground can buffer the increasing $\mathrm{CO}_{2}$ on the global C budget (Piao et al., 2009; Bruggemann et al., 2011; Pausch and Kuzyakov, 2018). Microorganisms also play an important role for $\mathrm{C}$ cycle and $\mathrm{CO}_{2}$ fixation (Long et al., 2015; Pratscher et al., 2011), but contributions made by active soil microorganisms in the field is less studied. Miltner et al. (2005) reported that the amount of fixed $\mathrm{CO}_{2}$ in soil microorganisms reaches up to $3 \%-5 \%$ of the respiration emissions (Miltner et al., 2005). Yuan et al. (2012) showed that soil autotrophic microorganisms can convert $\mathrm{CO}_{2}$ into soil organic matter (SOM) with an assimilation rate of about 0.0134 to $0.103 \mathrm{~g} \mathrm{~cm}^{-2} \mathrm{~d}^{-1}$. Regrettably, there is a lack of understanding of the importance and distribution of soil microbial $\mathrm{CO}_{2}$ fixation in paddy soils.

Nitrification, the biological oxidation of ammonia to nitrate via nitrite, is a quite important part of the global biochemical cycle (Galloway et al., 2008). As is well-known, autotrophic ammonia-oxidizing bacteria (AOB) perform the function of ammonia oxidation which is the first step of nitrification (Tourna et al., 2010). Meanwhile, Vuillemin et al. (2019) reported that nitrite-oxidizing bacteria (NOB) fix carbon via the rTCA cycle. This implies that $A O B$ and NOB have coupling effect between carbon and nitrogen cycle. Paddy fields are a unique anthropogenic aquatic ecosystem. Irrigation management causes oxygen rapid depletion below the soil surface, where an oxygen gradient can be taken shape within a few millimeters of the soil surface (Liesack et al., 2000). The activity of $A O B$ and $N O B$ may be regulated by oxygen deficiency. Furthermore, irrigation often leads to the accumulation of electron donors and the successive decrease of electron acceptors in soil organic matter, for instance nitrate and sulfate (Kimura, 2000). These changes in soil physiochemical properties will also lead to changes in $\mathrm{AOB}$ or $\mathrm{NOB}$ communities (Ke et al., 2013).

A field study for Simulating Climate Change (SCC) experiment was conducted since 2011 with free air $\mathrm{CO}_{2}$ enrichment and an elevated temperature in an annual ricewheat rotation system in Changshu, Jiangsu Province, China and many researches has been published based on this experiment (Liu et al., 2014; Cai et al., 2016; Wang et al.,
2016). Although a number of SCC experiments have been carried out for a broad range of questions (Del Galdo et al., 2006; Jin and Evans, 2007; Steven et al., 2014), the effects on soil microbial community, and particularly, the responses of active autotrophic microorganisms on elevated temperature and $\mathrm{CO}_{2}$ are still unknown. Stable isotope probing (SIP) of nucleic acids, a culture-independent method for targeting the active microbes, allows specific identification of organisms assimilating labeled substances, most commonly carbon from a particular ${ }^{13} \mathrm{C}$-labeled substrate (Radajewski et al., 2000; Dumont and Murrell, 2005). This method was available to identify the key autotrophic microbes which are the authentic drivers in the soil. We hypothesized that simultaneous existence of climate changes would result in more intense variation to bacterial community, since both $\mathrm{CO}_{2}$ and temperature increases could be set up at the same time which gives rise to accelerated environmental change. This study aimed to answer the following main questions: (1) how do composition and diversity of active bacterial communities respond to climate change? (2) What are the primary ecological processes modifying the active bacterial communities in different climate scenario?

To test this, we collected soils from the SCC field experiment and used DNA-SIP technique to recognize the active bacterial species assimilating ${ }^{13} \mathrm{CO}_{2}$ from the atmosphere. We aimed to record possible shifts in the dominant active bacteria and identify the responsible ecological processes under elevated temperature and $\mathrm{CO}_{2}$ in paddy soil.

\section{Materials and methods}

\subsection{The field experiment design and soil sampling}

A Simulated Climate Change (SCC) field experiment with an annual rice-wheat rotation has been running since 2011 in Changshu, Jiangsu Province, China $\left(31^{\circ} 30^{\prime} \mathrm{N}, 120^{\circ} 33^{\prime} \mathrm{E}\right)$. The mean annual temperature and mean precipitation in the region are $16^{\circ} \mathrm{C}$ and $1100-1200 \mathrm{~mm}$, respectively. A wheat (Triticum aestivum L.) - rice (Oryza sativa L.) crop rotation system has been maintained throughout the experiment. Seeds of rice and wheat are sown in November and June, respectively (Liu et al., 2014; Cai et al., 2016; Wang et al., 2016).

At the beginning of the experiment, the soil contained $16 \mathrm{~g} \mathrm{~kg}^{-1}$ organic matter, $1.9 \mathrm{~g} \mathrm{~kg}^{-1}$ total nitrogen $(\mathrm{N})$, and 0.9 $\mathrm{g} \mathrm{kg}^{-1}$ total phosphorus $(\mathrm{P})$ and had a $\mathrm{pH}\left(\mathrm{H}_{2} \mathrm{O}\right)$ of 7.0. The experiment has four treatments consisting of 1) $\mathrm{aCO}_{2}$-aTemp treatment (a control with ambient $\mathrm{CO}_{2}$ and temperature), 2) eTemp treatment (elevated temperature by $2^{\circ} \mathrm{C}$ in canopy air), 3) $\mathrm{eCO}_{2}$ treatment (elevated atmospheric $\mathrm{CO}_{2}$ concentration of $500 \mathrm{\mu mol} \mathrm{mol}^{-1}$ ), and 4) $\mathrm{eCO}_{2}$-eTemp treatment (elevated $\mathrm{CO}_{2}$ combined with elevated temperature). Each treatment was replicated in three plots (each plot $=50 \mathrm{~m}^{2}$ ) and arranged using a randomized design and details regarding $\mathrm{CO}_{2}$ concentration and temperature regulation during the field experiment have been described earlier (Liu et al., 2014). 
Urea $(46 \% \mathrm{~N})$ and compound fertilizer containing $\mathrm{N}, \mathrm{P}$ and $\mathrm{K}$ were used throughout the experiments and fertilization was applied four times during the rice and three times during the wheat crop seasons. Urea was applied two days before rice transplantation and wheat seeding at an average rate of 190 $\mathrm{kg} \mathrm{N} \mathrm{ha}^{-1}$ as a basal fertilizer. A compound fertilizer (375 $\mathrm{kg} \mathrm{ha}^{-1}$ on average) was applied as topdressing fertilizer after heading. Thereafter, urea was applied two times during the rice and once during the wheat crop season as a topdressing fertilizer at an average concentration of $150 \mathrm{~kg} \mathrm{~N} \mathrm{ha}^{-1}$. Paddy rice was irrigated with a continuous flooding regime with two periods of drainage mid-season. Soil samples (the top 0-20 $\mathrm{cm}$ ) were collected with a $2.5 \mathrm{~cm}$ diameter auger from three replicate plots within each treatment after the rice seeding in 2016. All samples were homogenized by passing through a $2.0 \mathrm{~mm}$ sieve after each soil sample was divided into two parts and approximately $200 \mathrm{~g}$ of fresh sample was stored at $4^{\circ} \mathrm{C}$ for the microbial DNA-SIP analysis and the second sample was air-dried for chemical analyses.

\subsection{Soil chemical measurements}

The soil moisture was determined by drying soils in an oven at $105^{\circ} \mathrm{C}$ for $12 \mathrm{~h}$. The concentrations of soil $\mathrm{NH}_{4}{ }^{+}$and $\mathrm{NO}_{3}{ }^{-}$ were measured with a continuous-flow stream autoanalyser (Autoanalyzer 3, Bran Luebbe, Norderstedt, Germany) after shaking with $0.01 \mathrm{M} \mathrm{CaCl}_{2}$ solution (1:10 of soil: solution by mass) for $30 \mathrm{~min}$. Soil organic carbon (SOC) and total nitrogen (TN) were measured with a CN Analyzer (Vario Max CN, Elementar, Hanau, Germany). The electrical conductivity of the saturated paste extraction (EC) was measured using a conductivity meter (DDS-307A, REX, Shanghai), and $\mathrm{pH}$ was determined with air-dried soil (soil:water, 1:5) by $\mathrm{pH}$ meter (PHS-3C, REX, Shanghai)

\subsection{Soil DNA-SIP microcosm experiment}

DNA stable isotope probing (DNA-SIP) was used to determine the functionally active microbes in present in soil samples. To this end, $10 \mathrm{~g}$ of oven-dried and sieved fresh soil samples with a $40 \%$ soil maximum water holding capacity were transferred into $120-\mathrm{mL}$ serum bottles which were sealed with rubber stoppers and aluminum caps for a 14-day pre-incubation period. Each independent soil sample for DNA-SIP microcosms was treated in two replicates with either ${ }^{13} \mathrm{CO}_{2}$ or ${ }^{12} \mathrm{CO}_{2}(100 \mathrm{~Pa})$ injections. Five percent $\mathrm{CO}_{2}\left(5 \% \mathrm{v} / \mathrm{v}{ }^{12} \mathrm{CO}_{2}\right.$ or ${ }^{13} \mathrm{CO}_{2}$ ) was added to the headspace, and ${ }^{13} \mathrm{CO}_{2}$ microcosms received $100 \mu{ }^{13} \mathrm{C}$-urea- $\mathrm{N} \mathrm{g}^{-1}$ once per week and the ${ }^{12} \mathrm{CO}_{2}$ microcosms received $100 \mu \mathrm{g}{ }^{12} \mathrm{C}$-urea- $\mathrm{N} \mathrm{g}^{-1}$ d.w.s once per week during the eight-week incubation period. Urea was added as a $\mathrm{N}$ source to simulate paddy soil environments in China which typically receive large amounts of $\mathrm{N}$ fertilizer. However, urea was only applied during the DNA-SIP experiment and not during the two-week long pre-incubation phase to reduce the dilution of ${ }^{13} \mathrm{CO}_{2}$ due to soil respiration. High soil urease activity rapidly hydrolyzed the urea into ammonium carbonate and ammonium carbonate easily released ammonia and $\mathrm{CO}_{2}$ (Shi et al., 2007). In addition, the added ${ }^{13} \mathrm{C}$-urea maintained a constant ${ }^{13} \mathrm{CO}_{2}$ release at a high concentration during the soil microcosm incubation. The ${ }^{13}$ C-urea (99 atom \% carbon) was purchased from the Shanghai Engineering Research Center of Stable Isotopes (Shanghai, China) and ${ }^{13} \mathrm{CO}_{2}$ (99 atom \% carbon) was purchased from Cambridge Isotope Laboratories, Inc. The ${ }^{12} \mathrm{CO}_{2}$ was produced by acidifying calcium carbonate. The bottles were sealed tightly with black butyl stoppers and incubated at $25^{\circ} \mathrm{C}$ in the dark for 56 days. Every week, synthetic air $\left(80 \% \mathrm{~N}_{2}, 20 \% \mathrm{O}_{2}\right)$ was used to flush the bottles and replenish with $5 \% \mathrm{CO}_{2}\left({ }^{12} \mathrm{CO}_{2}\right.$ or $\left.{ }^{13} \mathrm{CO}_{2}\right)$. Destructive sampling from each microcosm was performed at the end of the incubation period and the soil samples were transferred immediately to $\mathrm{a}-80^{\circ} \mathrm{C}$ freezer for subsequent molecular analysis.

2.4 DNA extraction, density gradient centrifugation and fractionation

A FastDNA Spin Kit for Soil (MP Biomedicals, Cleveland, $\mathrm{OH}$, USA) was used to extract DNA from the soil samples of the field experiment and microcosm experiment. The concentration and quantity of extracted soil DNA were determined photometrically by a Nanodrop ND-1000 UV-vis Spectrophotometer (Nano Drop, ND2000, Thermo Scientific, 111 Wilmington, DE). Density gradient centrifugation and fractionation were used for soil samples from the DNA-SIP experiment and performed as reported previously with some modifications (Wang et al., 2015). Briefly, $3 \mu \mathrm{g}$ of DNA was added to a $1.85 \mathrm{~g} \mathrm{~mL}^{-1} \mathrm{CsCl}$ gradient buffer $(0.1 \mathrm{M}$ Tris- $\mathrm{HCl}$, $0.1 \mathrm{M} \mathrm{KCl}, 1 \mathrm{mM}$ EDTA, $\mathrm{pH}=8.0$ ) with an initial $\mathrm{CsCl}$ buoyant density of $1.725 \mathrm{~g} \mathrm{~mL}^{-1}$, which was prepared by adjusting the refractive index to 1.4025 with an AR200 digital hand-held refractometer (Reichert, Inc., Buffalo, NY, USA). Density gradient centrifugation was performed in $5.1 \mathrm{~mL}$ Quick-Seal polyallomer ultracentrifugation tubes (Beckman Coulter, Palo Alto, CA, USA) in a VTi 90 vertical rotor (Beckman Coulter) and was subjected to centrifugation at $177000 \mathrm{~g}$ for $44 \mathrm{~h}$ at $20^{\circ} \mathrm{C}$. Different buoyant density DNA fractions were obtained by replacing the gradient medium with sterile water from the top of the ultracentrifuge tube using a syringe pump (Longer Pump. LSP01-1A, China) with controlled the flow rate at 0.38 $\mathrm{mL} \mathrm{min}^{-1}$. Finally, 14 DNA fractions were obtained with equal volumes of $380 \mu \mathrm{L}$, and the density of each collected fraction was determined from a small aliquot $(50 \mu \mathrm{L})$ using AR200 digital hand-held refractometer (Reichert, Inc., Buffalo, NY, USA). The DNA fractions were purified and then dissolved in $30 \mu \mathrm{L}$ of TE buffer as described previously (Freitag et al., 2006) before sequencing.

\subsection{High-throughput sequencing}

To verify the presence of ${ }^{13} \mathrm{C}$-DNA in the density fractions before high-throughput sequencing we tested two marker genes that could be used to identify autotrophic $\mathrm{CO}_{2}$-fixing bacteria: $c b b L$ and $a m o A$ genes. The $c b b L$ gene was chosen 
because it encodes the key active-site residue in the large subunit of ribulose-1,5-bisphosphate carboxylase oxygenase (RuBisCO) (Kusian and Bowien, 1997; Tabita et al., 2007) affecting $\mathrm{CO}_{2}$ fixation via the Calvin-Benson-Bassham (CBB) cycle (Ortiz et al., 2014). As a result, RuBisCO l-encoding $c b b L$ genes could be used as a functional marker to differentiate the heavy and light fraction in SIP. However, due to unknown reasons we failed to amplify the $c b b L$ genes in density fractions. As a result, we selected the bacterial amoA gene as the marker gene, which is indicative of autotrophic ammonia-oxidising bacteria, to distinguish the heavy and light fraction in DNA-SIP analysis. To quantify this, a quantitative real-time PCR was carried out in triplicate using an ABI 7500 real-time PCR system (Applied Biosystems, America) with SYBR Premix Ex Taq (TaKaRa) to determine gene abundances in fractionated DNA. The following targeted qPCR primers were used for the bacterial amo $A$ genes: amoA-1F (5'-GGG GTT TCT ACT GGT GGT-3') and amoA-2R (5'- CCC CTC KGS AAA GCC TTC TTC-3'). Each $25 \mu \mathrm{L}$ qPCR reaction contained $12.5 \mu \mathrm{L}$ of $S Y B R \circledast$ Premix Ex $\mathrm{Taq}^{\mathrm{TM}}, 1 \mu \mathrm{L}$ of DNA, $0.5 \mu \mathrm{L}$ of each primer $(10 \mu \mathrm{M}), 0.5 \mu \mathrm{L}$ of ROX Reference Dye II $(50 \times)$ and $10 \mu \mathrm{L}$ of sterile water. All $\mathrm{PCRs}$ started with an initial enzyme activation step performed at $95^{\circ} \mathrm{C}$ for $5 \mathrm{~min}$ followed by 40 cycles of $95^{\circ} \mathrm{C}$ for $5 \mathrm{~s}, 60^{\circ} \mathrm{C}$ for $34 \mathrm{~s}$, and a final temperature increase to $95^{\circ} \mathrm{C}$ for $15 \mathrm{~s}$. Data were collected after each annealing step. Standard curves were constructed by a 10 -fold serial dilution of the known copy numbers of plasmids harbouring the target gene. The efficiencies ranged from $102 \%$ to $103 \%$, and the $R^{2}$ values ranged from 0.998 to 0.999 .

Based on the qPCR results, ${ }^{13} \mathrm{C}$-DNA was accurately distinguished into heavy fractions of the DNA-SIP samples. The DNA present in the heavy fractions of DNA-SIP samples and DNA collected from the field experiment samples were subsequently characterized using Illumina MiSeq System at Shanghai Personal Biotechnology Co., Ltd. (Shanghai, China). To investigate the composition of the active bacterial communities, the V4-V5 region in the 16S rRNA gene was amplified using the primer pair 515F (5'- GTG CCA GCM GCC GCG GTA A-3') and 907R (5'- CCG TCA ATT CMT TTR AGT TT-3') (Krepski et al., 2012).

The raw high-throughput sequencing data was analyzed using the Quantitative Insights Into Microbial Ecology (QIIME) toolkit (Caporaso et al., 2010) and the UPARSE pipeline (Edgar, 2013). The DNA sequences were filtered using quality files, and the remaining sequences were trimmed with barcodes and forward primers and sequences with low quality (quality score $<20$, length $<300 \mathrm{bp}$ ) were excluded. And then the sequencing data were treated to remove chimeras from the data sets. After optimizing the sequences, the UPARSE pipeline was used to construct an OTU table. The 16S rRNA sequences were binned into OTUs using a $97 \%$ identity threshold, and the most abundant sequence from each OTU was selected as the representative sequence for that OTU. We used the SILVA database (https://www.arb-silva.de/, Version 119) to assign each representative sequence from
16S rRNA data to a taxon. All the OTUs belonging to archaea were removed because of the extremely low number of reads detected in all samples. The all selected active microbes were not autotrophic probably because of cross-feeding, which is nevertheless an important process that governs the growth and composition of microbial ecosystems in the exchange of essential metabolites. Some heterotrophic microbes inevitably incorporate ${ }^{13} \mathrm{C}$ into their DNA in this system and thus we referred to other studies to screen for the active autotrophs (Pratscher et al., 2011; Yuan et al., 2012; Long et al., 2015; Wang et al., 2015).

Ammonia-oxidizing bacteria (AOB) (Jia and Conrad, 2009) and nitrite-oxidizing bacteria (NOB) (Vuillemin et al., 2019) were identified as $\mathrm{CO}_{2}$ fixing bacteria in some previous researches. All of the sequences were deposited in the NCBI Sequence Read Archive database (accession numbers SRP135916).

\subsection{Statistical analysis}

ANOVA was used to compare the means for soil physicochemical and microbial diversity data with Duncan's least significant difference $(p=0.05)$ using IMB SPSS statistical software package version 20 (IBM Corporation, New York, USA). Principal component analysis (PCA) and PERMANOVA were used to analyze 16S rRNA communities in soils for all the treatments in R software with "vegan" package. To identify OTUs that were correlated with ${ }^{13} \mathrm{CO}_{2}$ assimilation, DESeq2 $\mathrm{R}$ package was used to analyze differential OTU relative abundance based on the negative binomial distribution in the heavy fractions of the ${ }^{13} \mathrm{C}$-treatments relative to the corresponding fractions from the ${ }^{12} \mathrm{CO}_{2}$-treated control (McMurdie and Holmes, 2014; Pepe-Ranney et al., 2016). Log2-fold change values higher than zero with adjusted $p$ values (FDR-adjusted $p$-value) lower than $5 \%$ were selected as ${ }^{13} \mathrm{C}$-labeled OTUs.

To evaluate the degree of non-random phylogenetic structure of our communities, we calculated the nearest relative index (NRI) using 'ses.mpd' $R$ function, $N R I$ is equivalent to 1 times the output of 'ses.mdp' (Kembel et al., 2010), in which the mean phylogenetic distance (MPD) for each OTU was weighted by its abundance, and the observed MPD was compared with the null distribution of MPD generated by the 1000 randomizations of "phylogeny.pool" null model. The NRI (nearest relatedness index) is a standardized measure of the mean pairwise phylogenetic distance of taxa in a sample (Webb et al., 2002), and through which we could infer the importance of niche-based and neutral processes in driving community assembly (Kembel, 2009). In general, a mean NRI across all samples that is significantly greater than zero is correlated with phylogenetic clustering, equal to zero with random, and less than zero with over-dispersion (Kembel, 2009). The significant difference between NRI and null expectation of zero was tested using two-tailed $t$-test at the $95 \%$ confidence level.

The representative sequences with the longest lengths for the labeled OTUs were selected for a subsequent construc- 
tion of phylogenetic tree, which was conducted with MEGA 6 through neighbor-joining trees using a Kimura 2-parameter distance model with 1000 bootstrap replicates. All analyses were conducted using IMB SPSS statistical software package version 20 (IBM Corporation, New York, USA) and R (2.15.3) and in all tests, $p$-values $<0.05$ were considered as statistically significant differences.

\section{Results}

3.1 Responses of the soil chemical properties to the climate change

As Fig. 1 and Table S1 showed, compared to the $\mathrm{aCO}_{2}$-aTemp soil, the $\mathrm{pH}$ increased for 0.18 units in the eTemp soil but decreased for 0.05 and 0.31 units in the $\mathrm{eCO}_{2}$ and $\mathrm{eCO}_{2}$ eTemp soil. Elevated temperature decreased both the total nitrogen (TN) and soil organic carbon (SOC) for about $7 \%$, while TN and SOC increased about $13 \%$ and $33 \%$ in eTemp and $\mathrm{eCO}_{2}$-eTemp soils, respectively. Elevated $\mathrm{CO}_{2}$ can increase the storage of soil $\mathrm{C}$ pools and nitrogen pools. However, $\mathrm{C}: \mathrm{N}$ ratio had a slight increase in treated soil compared to the control soil. As long as elevated temperature increased the electric conductivity $(E C)$ of the soil for $31.9 \%$ and $11.2 \%$ in the eTemp and $\mathrm{eCO}_{2}$-eTemp soils, while only elevated $\mathrm{CO}_{2}$ decreased the soil EC by $11.9 \%$.
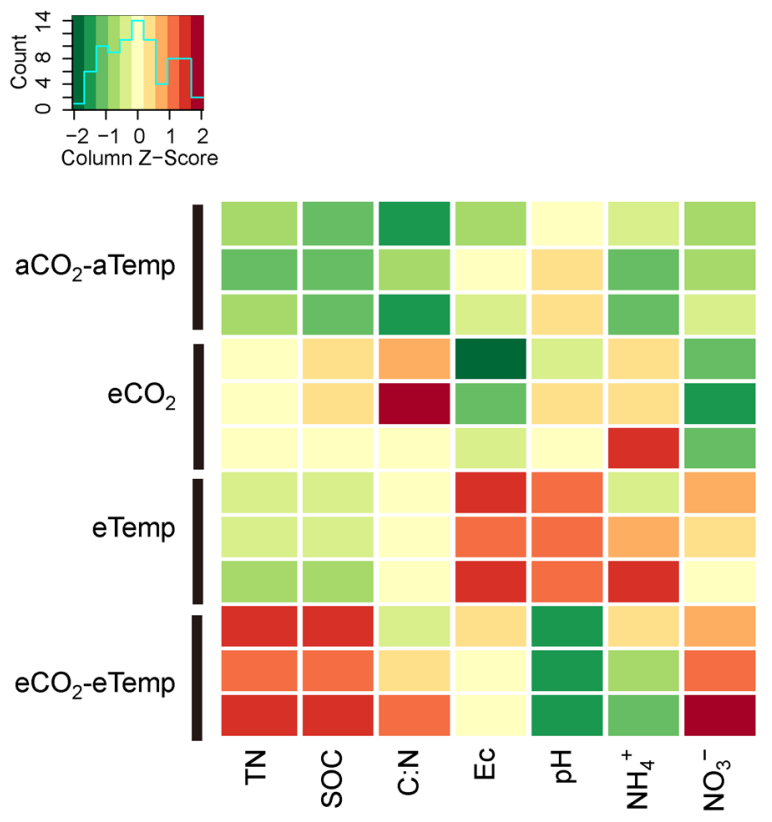

Fig. 1 Heatmap of the chemical properties of the four soils under climate change. SOC represents soil organic carbon, TN represents soil total nitrogen, DOC represents dissolved organic carbon, and $\mathrm{NH}_{4}{ }^{+}$and $\mathrm{NO}_{3}{ }^{-}$represent ammonium nitrogen and nitrate nitrogen, respectively. Each treatment has three replications. $\mathrm{aCO}_{2}$-aTemp: ambient $\mathrm{CO}_{2}$ and temperature; eTemp: elevated temperature; $\mathrm{eCO}_{2}$ : elevated $\mathrm{CO}_{2}$; eCO and elevated temperature.
3.2 Community composition of active bacteria assimilating $\mathrm{CO}_{2}$

The marker gene, ammonia-oxidizing bacterial (AOB) gene, well discriminated the ${ }^{13} \mathrm{C}$-DNA and ${ }^{12} \mathrm{C}$-DNA in SIP into 15 density-gradient fractions (Fig. 2). In the ${ }^{12} \mathrm{C}-\mathrm{CO}_{2}$ microcosms, the relative abundance of the AOB gene was mainly distributed in the buoyant density 10-11th fractions (light fraction). DNA in ${ }^{13} \mathrm{C}-\mathrm{CO}_{2}$ microcosms distributed in the 5-6th fractions (heavy fraction). There was only obvious marker gene in the heavy fractions, indicating that active microorganisms took advantage the ${ }^{13} \mathrm{C}-\mathrm{CO}_{2}$ into the DNA and all ${ }^{13} \mathrm{C}$ $\mathrm{CO}_{2}$ treatments successfully labeled the DNA. Differently labeled OTU abundance analysis was conducted by DESeq2. The volcano plot indicated that 16, 2, 13 and 19 OTUs were labeled in $\mathrm{aCO}_{2}$-aTemp, eTemp, eCO 2 and $\mathrm{eCO}_{2}$-eTemp treatments, respectively (Fig. S1a). A Venn diagram showed (Fig. S1b) that there was only one OTU in the intersection of the all treatments, which allowed us to infer that this OTU may be widespread in active species in the paddy soils. The ${ }^{13} \mathrm{C}$ labeled OTUs mainly belonged to Nitrosomonadaceae, Bradyrhizobiaceae, Rhizobiaceae, Sphingomonadaceae, and Xanthomonadaceae (Fig. 3). Nitrosomonadaceae was generally abundant in all soils, while the eTemp soil only contained Nitrosomonadaceae in the ${ }^{13} \mathrm{C}$ labeled fraction. The $\mathrm{eCO}_{2}$ soil had the most categories of active microbes that included the typical families, mainly including Microbacteriaceae, Nocardiaceae and Methylobacteriaceae. However, the $\mathrm{aCO}_{2}$-aTemp and $\mathrm{eCO}_{2}$-eTemp soils had the most similar composition (Fig. 3). PCA (Fig. 4A) revealed clear temperature-only and $\mathrm{CO}_{2}$-only effects on shift of active bacterial community composition, which somehow counteract toward an only smooth community variation if both factors increase simultaneously. The result of the two-way PERMANOVA analysis (Fig. 4B) more precisely revealed the aforementioned consequence, demonstrating that elevating temperatures or $\mathrm{CO}_{2}$ individually dramatically affected community composition, but the interaction had little effect on the community composition.

\subsection{Phylogenetic analysis of autotrophic bacteria}

The nearest relative index (NRI) of the active bacterial community declined in the simulate climate change conditions, especially dramatically declined in the $\mathrm{eCO}_{2}$ soil $(\mathrm{NRI}<0)$ (Fig. 5). These results indicate that the phylogenetic structure of active bacterial communities in the control soil and in the eTemp soil were all the result of stochastic ( = random) events, the eTemp trended to result in the clustered community more dispersed than control, and the elevated $\mathrm{CO}_{2}$ made the soil active bacterial community over-dispersed.

According to the Fig. S3, $28.9 \%$ of active OTUs were founded to be two autotrophic groups: ammonia-oxidizing bacteria $(A O B)$ and nitrite-oxidizing bacteria (NOB). A total of seven OTUs were identified as AOB (Fig. S3) that were divided to three groups including Nitrosospira cluster 3, Nitrosomonas cluster $6 \mathrm{~b}$ and Nitrosomonas cluster 8 

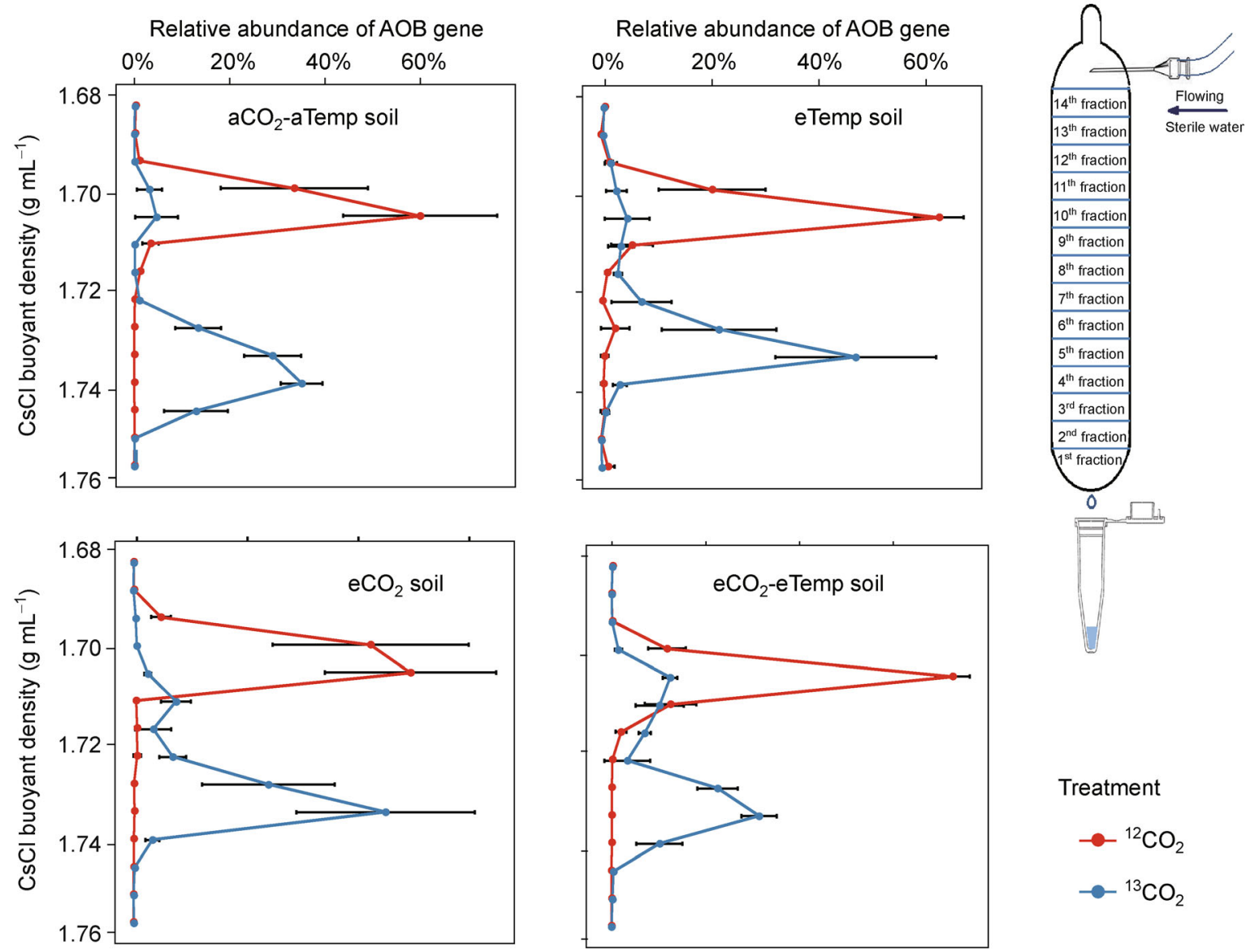

Treatment

$$
\begin{aligned}
& -{ }^{12} \mathrm{CO}_{2} \\
& -{ }^{13} \mathrm{CO}_{2}
\end{aligned}
$$

Fig. 2 The quantitative distribution of the $A O B$ gene across the entire buoyant density gradient of the DNA fractions from soil microcosms incubated with ${ }^{12} \mathrm{CO}_{2}$ and ${ }^{13} \mathrm{CO}_{2}$ for 56 days. $\mathrm{aCO}_{2}$-aTemp: ambient $\mathrm{CO}_{2}$ and temperature; eTemp: elevated temperature; $\mathrm{eCO}_{2}$ : elevated $\mathrm{CO}_{2} ; \mathrm{eCO}_{2}$-eTemp: elevated $\mathrm{CO}_{2}$ and elevated temperature.

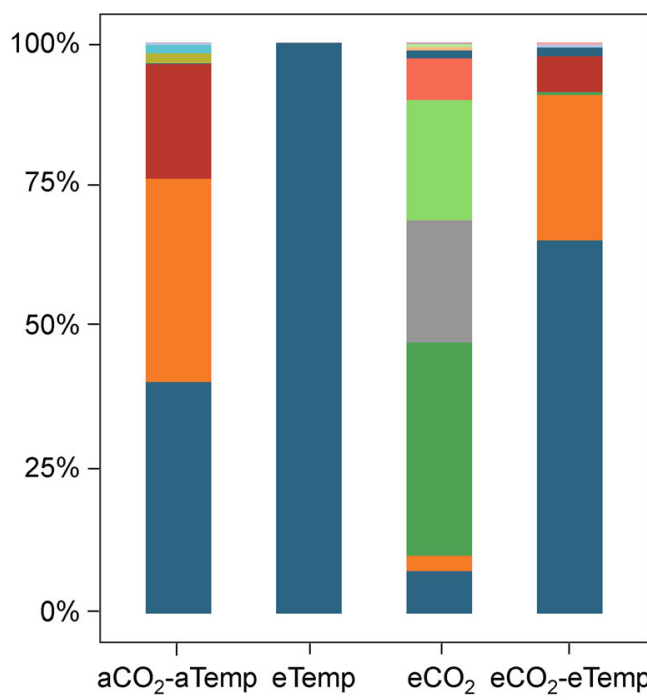

\section{Family}

Oxalobacteraceae

Hyphomicrobiaceae

Fusobacteriaceae

Methylobacteriaceae

Pseudomonadaceae

Rhizobiaceae

Sphingomonadaceae

Xanthomonadaceae

Unclassified

Chitinophagaceae

Nocardiaceae

Microbacteriaceae

Nitrospiraceae

Brucellaceae

Bradyrhizobiaceae

Nitrosomonadaceae

Fig. 3 Relative abundance of ${ }^{13} \mathrm{C}$ labeled OTUs in four soils after 56 days' incubation with ${ }^{13} \mathrm{CO}_{2} \cdot \mathrm{aCO}_{2}$-aTemp: ambient $\mathrm{CO}_{2}$ and temperature; eTemp: elevated temperature; $\mathrm{eCO}_{2}$ : elevated $\mathrm{CO}_{2} ; \mathrm{eCO}_{2}$-eTemp: elevated $\mathrm{CO}_{2}$ and elevated temperature. 

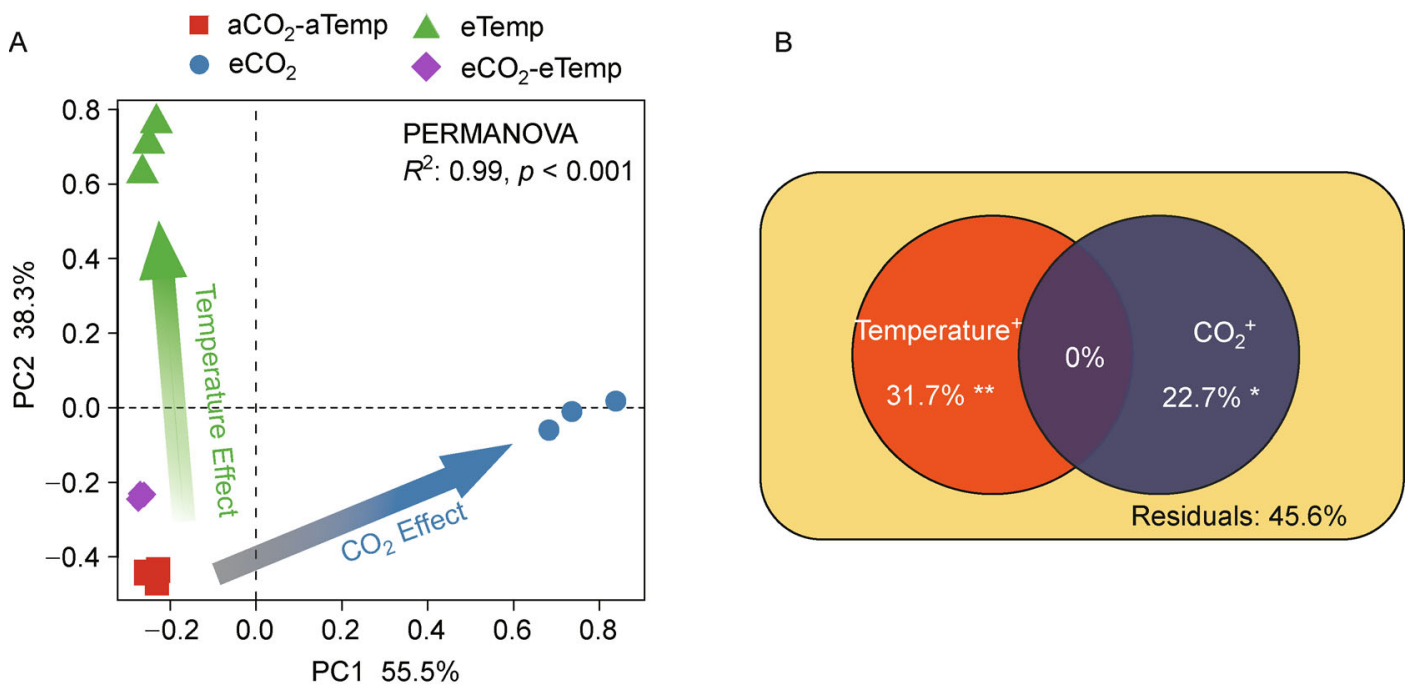

Fig. 4 (A) Principal component analysis (PCA) of ${ }^{13} \mathrm{C}$ labeled OTU matrices from: $\mathrm{aCO}_{2}$-aTemp: ambient $\mathrm{CO}_{2}$ and temperature; eTemp: elevated temperature; eCO $\mathrm{CO}_{2}$ : elevated $\mathrm{CO}_{2} ; \mathrm{eCO}_{2}$-eTemp: elevated $\mathrm{CO}_{2}$ and elevated temperature. (B) Two-way PERMANOVA was used to analyze the effects of elevated temperature and elevated $\mathrm{CO}_{2}$ on community composition of active OTUs.

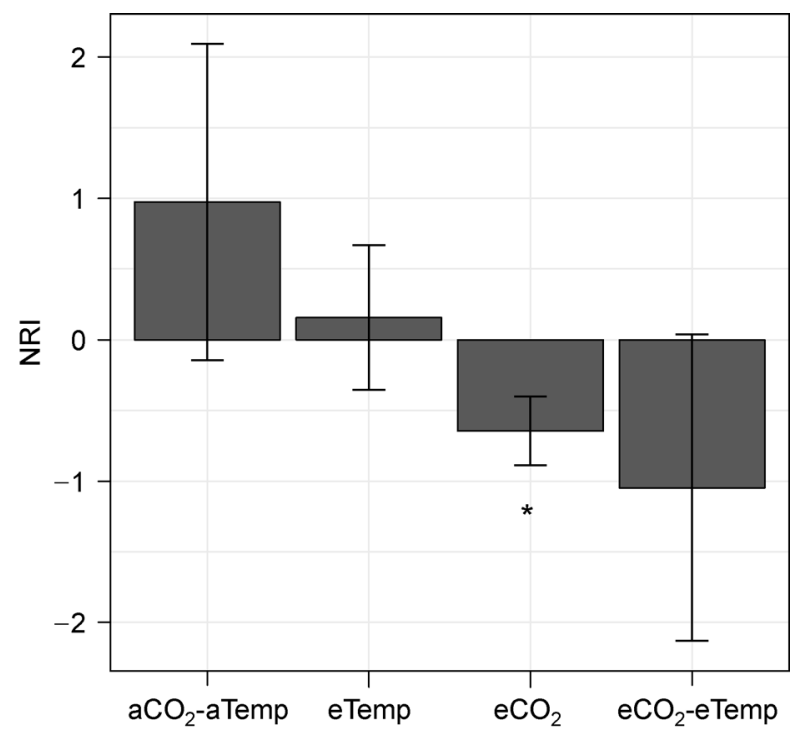

Fig. 5 The nearest relative index (NRI) of active bacterial community $\left({ }^{13} \mathrm{CO}_{2}\right.$ labeled $)$ varied in $\mathrm{aCO}_{2}$-aTemp: ambient $\mathrm{CO}_{2}$ and temperature; eTemp: elevated temperature; eCO $\mathrm{CO}_{2}$ : elevated $\mathrm{CO}_{2}$; eCO -eTemp: elevated $\mathrm{CO}_{2}$ and elevated temperature. Bars represent means $\pm \mathrm{SDs}(n$ $=3$ ). Asterisk indicates that the NRI is significantly different from zero after $t$-test $\left({ }^{*} p<0.05\right)$

(Fig. 6A). The $\mathrm{eCO}_{2}$-eTemp soil had the most species of active $\mathrm{AOB}$ widely distributed in all three groups. However, the $\mathrm{eCO}_{2}$ soil only contained one species of active AOB (OTU4). OTU4 was the most dominant active $\mathrm{AOB}$ in the $\mathrm{aCO}_{2}$-aTemp, $\mathrm{eCO}_{2}$ and $\mathrm{eCO}_{2}$-eTemp treatments, at $95.6 \%, 100 \%$ and $82.5 \%$, respectively (Fig. 6A). The primary AOB species in the eTemp treatment was OTU24 $(80.4 \%)$, which belongs to the
Nitrosomonas cluster 8 . Thus, changes in climate reshape the active autotrophic microbial composition, leading to a low diversity of $\mathrm{AOB}$ in the $\mathrm{eCO}_{2}$ soil and higher diversity in the $\mathrm{eCO}_{2}$-eTemp soil.

Only the $\mathrm{aCO}_{2}$-aTemp and $\mathrm{eCO}_{2}$-eTemp soil had active autotrophic NOB species detected (Fig. 7A). Elevated $\mathrm{CO}_{2}$ or temperature alone let to disappearance of the active autotrophic NOB. Under ambient conditions $\left(\mathrm{aCO}_{2}\right.$-aTemp), more NOB species were widespread, including OTU253 (2.0\%), OTU131 (1.7\%), OTU178 (5.4\%), OTU308 (3.5\%) and OTU12 (87.4\%). The $\mathrm{eCO}_{2}$-eTemp reduced the number of NOB species, which only contained OTU178 and OTU12. However, OTU12 occupied $97.7 \%$ of active $\mathrm{NOB}$ in the $\mathrm{eCO}_{2}$ eTemp soil, which was the primary active autotrophic NOB in accordance with the $\mathrm{aCO}_{2}$-aTemp soil. Thus, $\mathrm{NOB}$ was more sensitive to temperature and $\mathrm{CO}_{2}$ increase than $\mathrm{AOB}$.

\section{Discussion}

Elevated atmospheric $\mathrm{CO}_{2}$ concentrations enhance plant photosynthesis and root growth, leading to an increased carbon input into the soil (Austin et al., 2009; Pritchard, 2011; Liu et al., 2014). Elevated $\mathrm{CO}_{2}$ level increases SOC also in paddy soils (Chen et al., 2016), possibly through higher root rhizodeposition and organic matter release. Previous studies have reported that temperature increase stimulates net primary productivity (Trumbore, 1997) and soil respiration (Luo, 2007) in most terrestrial ecosystems. However, increase in temperature can also increase microbial activity (Blagodatskaya and Kuzyakov, 2013) resulting in the acceleration of SOC decomposition (Luo, 2007). Furthermore, elevated temperature likely decreases crop productivity owing to the enhanced respiration and decomposition of photosynthesized 


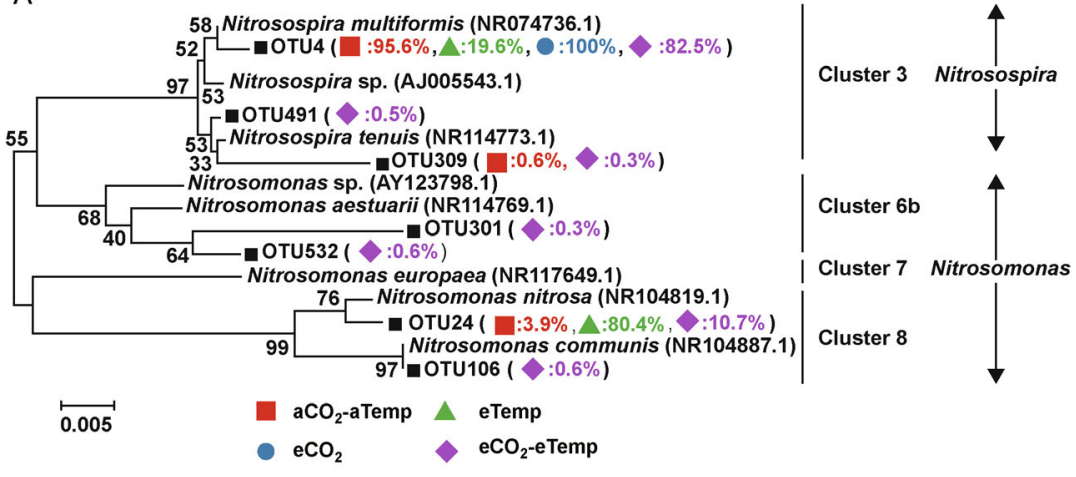

B

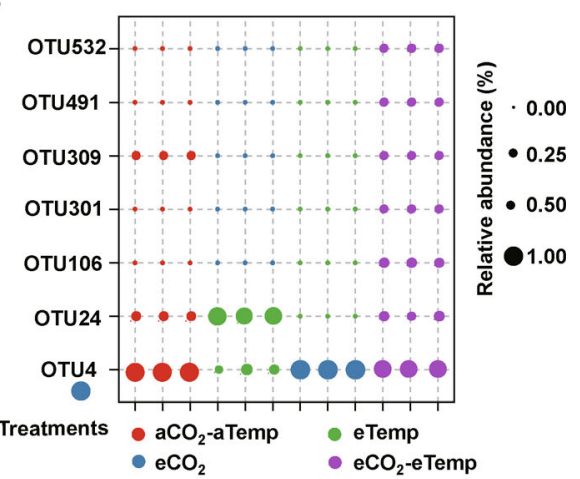

Fig. 6 (A) Neighbor-joining tree analysis of ${ }^{13} \mathrm{CO}_{2}$ labeled OTUs combined with relative abundance of AOB from four soils after 56 days' incubations with ${ }^{13} \mathrm{CO}_{2}$. Bootstrap values higher than $50 \%$ are indicated at branch nodes. The scale bar represents $2 \%$ nucleic acid sequence divergence. (B) Bubble plot represent abundances of labeled OTUs corresponding to the bubble sizes. The four colors represent the four treatments: $\mathrm{aCO}_{2}$-aTemp: ambient $\mathrm{CO}_{2}$ and temperature; eTemp: elevated temperature; $\mathrm{eCO}_{2}$ : elevated $\mathrm{CO}_{2} ; \mathrm{eCO}_{2}$-eTemp: elevated $\mathrm{CO}_{2}$ and elevated temperature.

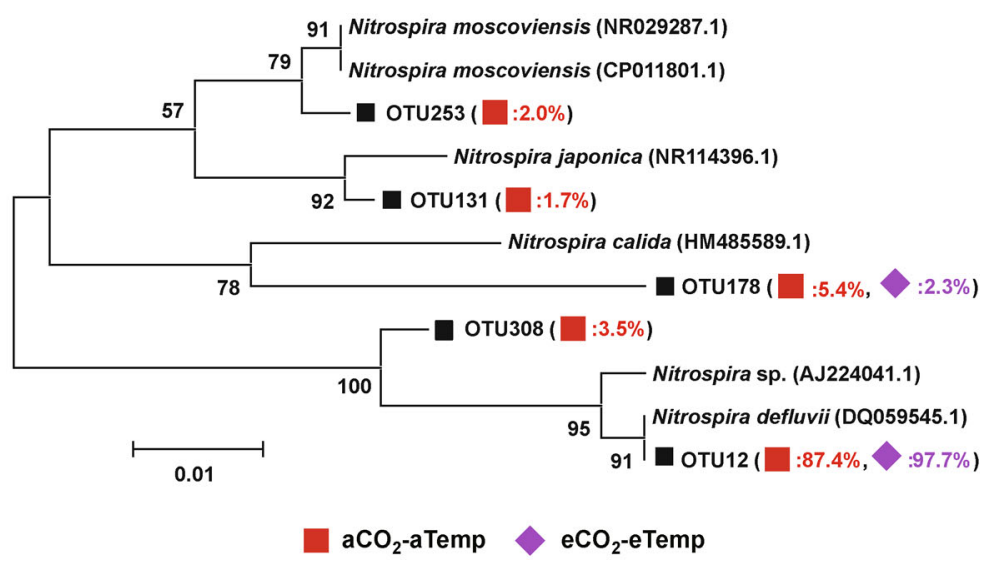

B

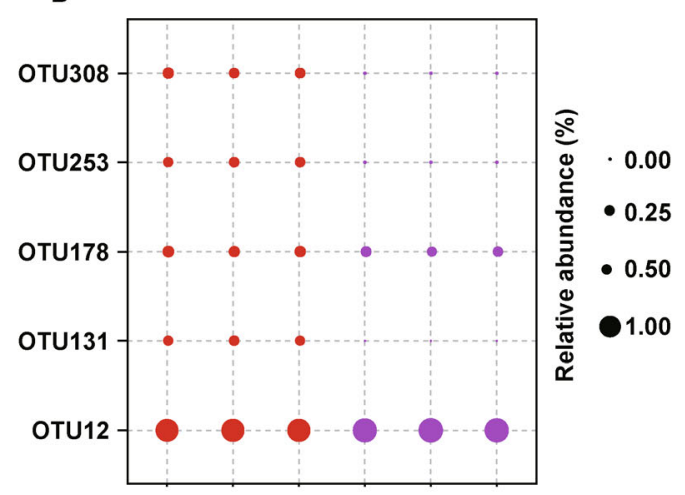

Treatments $\bullet \mathrm{aCO}_{2}$-aTemp $\bullet \mathrm{eCO}_{2}$-eTemp

Fig. 7 (A) Neighbor-joining tree analysis of ${ }^{13} \mathrm{CO}_{2}$ labeled OTUs combined with relative abundance of NOB form different treated soils after 56 days' incubations with ${ }^{13} \mathrm{CO}_{2}$. Bootstrap values higher than $50 \%$ are indicated at branch nodes. The scale bar represents $2 \%$ nucleic acid sequence divergence. (B) Bubble plot represent different abundances of labeled OTUs with different bubble sizes. The different colors represent the different treatments: $\mathrm{aCO}_{2}$-aTemp: ambient $\mathrm{CO}_{2}$ and temperature; $\mathrm{eCO}_{2}$ eTemp: elevated $\mathrm{CO}_{2}$ and elevated temperature.

biomass, thus reducing carbon input into soil (Pan et al., 2004).

Previously it has been suggested that soil microbial diversity changes in response to $\mathrm{pH}$, SOC, moisture and so on (Liu et al., 2014). In this study, the $\beta$-diversity of active bacteria varied under climate change scenarios (Fig. 4A) and the main factors affecting the community composition were EC, $\mathrm{NO}_{3}{ }^{-}$and $\mathrm{NH}_{4}{ }^{+}$(Fig. S2). However, the impact of the combination of elevated temperature and $\mathrm{CO}_{2}$ on $\beta$-diversity was far less than a single disturbance. This is in inconsistent with the two having additive effects on microbial communities in temperate agricultural soils (Pritchard, 2011). Some studies have reported that $\alpha$-diversity and $\beta$-diversity shifts donnot occur at the same time and that $\beta$-diversity responds faster to environmental changes than $\alpha$-diversity (Xiong et al., 2014;
Zhu et al., 2016). Changes in active microbial diversity are likely to be different from those in general. To our interpretation, here the microbial functioning responded rapidly to the environment, and the compositional change of active microbes at taxonomic level could lag the variation in functioning.

Furthermore, we found that active microbial communities were phylogenetically random in the control, eTemp and $\mathrm{eCO}_{2}$-eTemp treatments and over-dispersed in the $\mathrm{eCO}_{2}$ treatment (Fig. 5), suggesting that the co-occurring active microorganisms were more distantly related in only high $\mathrm{CO}_{2}$ concentration soil. The community in soil with only high $\mathrm{CO}_{2}$ concentration is composed of less phylogenetically related species than expected by chance (overdispersal), and competition is likely to dominate because closely related or 
identical species struggle for the same resources and therefore do not co-occur. Few studies showed that microbial communities were frequently clustered in natural undisturbed ecosystems (Saks et al., 2013; Horn et al., 2014; Liu et al., 2014). In this experiment, however, the soils under $\mathrm{aCO}_{2}-$ aTemp may also be random in ecological process. Nevertheless, the shifts of assemble patterns in $\mathrm{eCO}_{2}$ treatment were likely to be related to increasing crop carbohydrates. Elevated $\mathrm{CO}_{2}$ was often been found increasing rice primary biomass production, and therefore could lead to more carbon allocation into the soil for microbial utilization (Inubushi et al., 2003). High nutrient input results in a decrease in abundance of dominate species of Glomus within AMF (arbuscular mycorrhizal fungi) due to more opportunities for successful colonization of other genera of AMF (Liu et al., 2014). Thus, probably, in certain scenario, more resources may tend to increase competition between phylogenetically similar microorganisms resulting in the community change, for instance, under the scenario of elevated $\mathrm{CO}_{2}$ in agroecosystem.

The active microbes that probably primarily determine the change of overall microbial community, account only a small proportion in the overall community. And the labeled microbial groups are not all autotrophic microbes probably because of cross-feeding. However, autotrophic microorganisms are the most important group of active microorganisms in our study, because we added ${ }^{13} \mathrm{C}-\mathrm{CO}_{2}$, and autotrophy is particularly important in the whole process. $28.9 \%$ of active OTUs were founded to be identified as ammonia-oxidizing bacteria (AOB) and nitrite-oxidizing bacteria (NOB) (Fig. S2).

Nitrosospira cluster 3 was the predominant $A O B$ species in the $\mathrm{aCO}_{2}$-aTemp, $\mathrm{eCO}_{2}$ and $\mathrm{eCO}_{2}$-eTemp soil. This result was not surprising: previous studies reported that Nitrosospira species are prevalent in terrestrial ecosystems, especially in agricultural soils (He et al., 2007; Shen et al., 2008; Jiang et al., 2014; Ouyang et al., 2016). However, the dominant species of AOB changed Nitrosospira clusters into Nitrosomonas clusters in the eTemp soil. Thus, elevated temperature alone had a much stronger effect on autotrophic AOB in paddy soil than elevated $\mathrm{CO}_{2}$ alone. Microbial growth and vital functions are dependent on enzyme activity, which is temperature-sensitive (Razavi et al., 2017). Enzymes of microorganisms can directly respond to warming through physiological and genetic change (Blagodatskaya and Kuzyakov, 2013; Karhu et al., 2014). These variations may result in different microbial activity or loss of competitiveness, leading to the shift in microbial community diversity. In addition, soil warming could lead to functional gene expression, accelerate intracellular enzyme kinetics, and increase microbial cell turnover (Zhou et al., 2012; Nie et al., 2013; Hagerty et al., 2014). Due to microbial survival in dependent on enzyme functional activity (Burns 1982), the inactivity of certain intercellular enzymes under warming could be one of the factors leading to the change of $A O B$.

Soils containing Nitrosomonas phylotypes could be preadapted to relatively high temperatures and these phylotypes may have remained less active or dormant at lower temperatures (de la Torre et al., 2008; Hatzenpichler et al., 2008; Lennon and Jones, 2011). Nonetheless, elevated $\mathrm{CO}_{2}$ affects the $\mathrm{CO}_{2}$ concentrations within the soils only marginally (Drigo et al., 2008) and thus unlikely causes direct changes in the community composition. Numerous experiments have reported that under field conditions, elevated $\mathrm{CO}_{2}$ concentration can intensify leaf photosynthesis in C3 species, such as wheat, rice, and many other food crops, resulting in promoted growth and increased yields (Horie et al., 2000; Kimball et al., 2002; Kim et al., 2003). In general, the amount of root exudates is positively correlated with the plant growth yield. Due to higher productivity, more carbon sources such as plant residues and root exudates, are allocated into the soils (Kuzyakov and Domanski, 2000). Thus, the above ground growth dynamics feed back to the soil microbial community composition via root exudates (Lange et al., 2015; Prober et al., 2015). Elevated $\mathrm{CO}_{2}$ increases the input of plant residue first, consequently affecting the microbial communities (Singh et al., 2010). According to our results (Fig. 1), increasing the temperature and $\mathrm{CO}_{2}$ at the same time can result in more $\mathrm{C}$ and $\mathrm{N}$ accumulation in soil. During simultaneous elevation of the $\mathrm{CO}_{2}$ and temperature, more resources are available for the active microbes, which could lead to an increase in the number of species and change the composition of active microbes. To our interpretation, this is the reason why more OTUs of Nitrosospira and Nitrosomonas detected under the combination of elevated $\mathrm{CO}_{2}$ and temperature. Moreover, the $\mathrm{eCO}_{2}$-eTemp treatment altered the composition of autotrophic $A O B$ to a certain extent, stimulated more autotrophic $A O B$ to be active, particularly, the Nitrosomonas relative abundance increased from $3.8 \%$ to $10.7 \%$ (Fig. 6A). To sum up, simultaneous elevation of the $\mathrm{CO}_{2}$ and temperature makes the community composition of active autotrophic bacteria much closer to the ambient condition treatment.

The results regarding to the active autotrophic NOB also revealed that the $\mathrm{NOB}$ composition in soil subjected to $\mathrm{eCO}_{2-}$ eTemp was similar to the composition in soil with $\mathrm{aCO}_{2}$ aTemp, and the similarity is more pronounced than that found between the AOB communities in paddy soils. The change in composition of active autotrophic $\mathrm{AOB}$ and $\mathrm{NOB}$ could be to some extent attributed to the influence of plant root secreted oxygen. Lack of oxygen prevents nitrification in most soils (Geisseler et al., 2017), resulting in nitrifying microorganisms not getting enough resource and energy. As mentioned above, the higher inputs of plant root-secreted oxygen could be a key factor influencing the microbial communities indirectly under climate change, especially under elevated $\mathrm{CO}_{2}$. This contrasts with the results in upland soils (increase of nitrification with warming) (Gao et al., 2016; Geisseler et al., 2017), because much less $\mathrm{O}_{2}$ is available and $\mathrm{O}_{2}$ is much faster depleted by overflooding in paddy soils. Another point is noteworthy: although active autotrophic NOB were not detected in the eTemp soil and $\mathrm{eCO}_{2}$ soil, it did not lead to loss of nitrite oxidation function in soils. The capacity of DNA- 
SIP depends on cell replication, thus excluding microbes that might be active but not replicating (Pritchard, 2011). RNA-SIP would be better for generating information regarding activity and it should be used instead of DNA-SIP to better explore active microorganism.

\section{Conclusions}

Increase of temperature, $\mathrm{CO}_{2}$ or both shift the composition mainly of active microbes in paddy soils. $\mathrm{AOB}$ and $\mathrm{NOB}$ are major autotrophs in paddy soils. Increase of temperature for $2^{\circ} \mathrm{C}$ or increase of $\mathrm{CO}_{2}$ concentration for $500 \mu \mathrm{mol} \mathrm{mol}^{-1}$ deactivate the NOB below the detection limit and decrease the OTU number of $\mathrm{AOB}$ by $33 \%$ and $66 \%$, respectively. In comparison with the ambient conditions, increasing both $\mathrm{CO}_{2}$ and temperature could recover activities of certain NOBs from the deactivated situations and stimulated more active OTUs of AOB (for instance, OTU301 and OTU532 belonging to Nitrosomonas cluster $6 \mathrm{~b}$ ) in the soil. Taken together, the individual effect of elevated temperature or $\mathrm{CO}_{2}$ on the changes in active microbial community is greater than the additive effect.

\section{Acknowledgments}

This work was supported by the National Key Research and Development Program of China (2017YFD0200805), the Special Fund for Agriculture Profession (20150312205) and the Innovative Research Team Development Plan of the Ministry of Education of China (IRT_17R56). We profoundly thank Dr. Lauri Mikonranta for insightful comments and suggestions for the manuscript.

\section{Electronic supplementary material}

Supplementary material is available in the online version of this article at https://doi.org/10.1007/s42832-020-0044-4 and is accessible for authorized users.

\section{References}

Austin, E.E., Castro, H.F., Sides, K.E., Schadt, C.W., Classen, A.T., 2009. Assessment of 10 years of $\mathrm{CO}_{2}$ fumigation on soil microbial communities and function in a sweetgum plantation. Soil Biology \& Biochemistry 41, 514-520.

Blagodatskaya, E., Kuzyakov, Y., 2013. Active microorganisms in soil: Critical review of estimation criteria and approaches. Soil Biology \& Biochemistry 67, 192-211.

Bruggemann, N., Gessler, A., Kayler, Z., Keel, S.G., Badeck, F., Barthel, M., Boeckx, P., Buchmann, N., Brugnoli, E., Esperschutz, J., Gavrichkova, O., Ghashghaie, J., Gomez-Casanovas, N., Keitel, C., Knohl, A., Kuptz, D., Palacio, S., Salmon, Y., Uchida, Y., Bahn, M., 2011. Carbon allocation and carbon isotope fluxes in the plant-soil-atmosphere continuum: a review. Biogeosciences 8 ,
3457-3489.

Burns, R.G., 1982. Enzyme activity in soil: location and a possible role in microbial ecology. Soil Biology \& Biochemistry 14, 423-427.

Cai, C., Yin, X., He, S., Jiang, W., Si, C., Struik, P.C., Luo, W., Li, G., Xie, Y., Xiong, Y., Pan, G., 2016. Responses of wheat and rice to factorial combinations of ambient and elevated $\mathrm{CO}_{2}$ and temperature in FACE experiments. Global Change Biology 22, 856-874.

Caporaso, J.G., Kuczynski, J., Stombaugh, J., Bittinger, K., Bushman, F.D., Costello, E.K., Fierer, N., Pena, A.G., Goodrich, J.K., Gordon, J.I., Huttley, G.A., Kelley, S.T., Knights, D., Koenig, J.E., Ley, R.E., Lozupone, C.A., McDonald, D., Muegge, B.D., Pirrung, M., Reeder, J., Sevinsky, J.R., Turnbaugh, P.J., Walters, W.A., Widmann, J., Yatsunenko, T., Zaneveld, J., Knight, R., 2010. QIIME allows analysis of high-throughput community sequencing data. Nature Methods 7, 335-336.

Chen, Z., Zhang, J., Xiong, Z., Pan, G., Müller, C., 2016. Enhanced gross nitrogen transformation rates and nitrogen supply in paddy field under elevated atmospheric carbon dioxide and temperature. Soil Biology \& Biochemistry 94, 80-87.

Courchamp, F., Hoffmann, B.D., Russell, J.C., Leclerc, C., Bellard, C., 2014. Climate change, sea-level rise, and conservation: keeping island biodiversity afloat. Trends in Ecology \& Evolution 29, 127 130.

de la Torre, J.R., Walker, C.B., Ingalls, A.E., Konneke, M., Stahl, D.A., 2008. Cultivation of a thermophilic ammonia oxidizing archaeon synthesizing crenarchaeol. Environmental Microbiology 10, 810 818.

Del Galdo, I., Oechel, W.C., Cotrufo, M.F., 2006. Effects of past, present and future atmospheric $\mathrm{CO}_{2}$ concentrations on soil organic matter dynamics in a chaparral ecosystem. Soil Biology \& Biochemistry 38, 3235-3244.

Drigo, B., Kowalchuk, G.A., van Veen, J.A., 2008. Climate change goes underground: effects of elevated atmospheric $\mathrm{CO}_{2}$ on microbial community structure and activities in the rhizosphere. Biology and Fertility of Soils 44, 667-679.

Dumont, M.G., Murrell, J.C., 2005. Stable isotope probing -linking microbial identity to function. Nature Reviews. Microbiology 3 , 499-504.

Edgar, R.C., 2013. UPARSE: highly accurate OTU sequences from microbial amplicon reads. Nature Methods 10, 996-998.

Freitag, T.E., Chang, L., Prosser, J.I., 2006. Changes in the community structure and activity of betaproteobacterial ammonia-oxidizing sediment bacteria along a freshwater-marine gradient. Environmental Microbiology 8, 684-696

Galloway, J.N., Townsend, A.R., Erisman, J.W., Bekunda, M., Cai, Z., Freney, J.R., Martinelli, L.A., Seitzinger, S.P., Sutton, M.A., 2008. Transformation of the nitrogen cycle: recent trends, questions, and potential solutions. Science 320, 889-892.

Gao, H., Chen, X., Wei, J., Zhang, Y., Zhang, L., Chang, J., Thompson, M.L., 2016. Decomposition dynamics and changes in chemical composition of wheat straw residue under anaerobic and aerobic conditions. PLoS One 11, e0158172.

Ge, T., Liu, C., Yuan, H., Zhao, Z., Wu, X., Zhu, Z., Brookes, P., Wu, J., 2015. Tracking the photosynthesized carbon input into soil organic carbon pools in a rice soil fertilized with nitrogen. Plant and Soil 
$392,17-25$.

Geisseler, D., Linquist, B.A., Lazicki, P.A., 2017. Effect of fertilization on soil microorganisms in paddy rice systems-A meta-analysis. Soil Biology \& Biochemistry 115, 452-460.

Hagerty, S.B., Van Groenigen, K.J., Allison, S.D., Hungate, B.A., Schwartz, E., Koch, G.W., Kolka, R.K., Dijkstra, P., 2014. Accelerated microbial turnover but constant growth efficiency with warming in soil. Nature Climate Change 4, 903-906.

Hatzenpichler, R., Lebedeva, E.V., Spieck, E., Stoecker, K., Richter, A., Daims, H., Wagner, M., 2008. A moderately thermophilic ammonia-oxidizing crenarchaeote from a hot spring. Proceedings of the National Academy of Sciences of the United States of America 105, 2134-2139.

He, J., Shen, J., Zhang, L., Zhu, Y., Zheng, Y., Xu, M., Di, H., 2007. Quantitative analyses of the abundance and composition of ammonia-oxidizing bacteria and ammonia-oxidizing archaea of a Chinese upland red soil under long-term fertilization practices. Environmental Microbiology 9, 2364-2374.

Horie, T., Baker, J.T., Nakagawa, H., Matsui, T., Kim, H.Y., 2000. Crop ecosystem responses to climatic change: rice. Climate Change and Global Crop Productivity, 81-106.

Horn, S., Caruso, T., Verbruggen, E., Rillig, M.C., Hempel, S., 2014. Arbuscular mycorrhizal fungal communities are phylogenetically clustered at small scales. ISME Journal 8, 2231-2242.

Inubushi, K., Furukawa, Y., Hadi, A., Purnomo, E., Tsuruta, H., 2003. Seasonal changes of $\mathrm{CO}_{2}, \mathrm{CH}_{4}$ and $\mathrm{N}_{2} \mathrm{O}$ fluxes in relation to landuse change in tropical peatlands located in coastal area of South Kalimantan. Chemosphere 52, 603-608.

Jia, Z., Conrad, R., 2009. Bacteria rather than Archaea dominate microbial ammonia oxidation in an agricultural soil. Environmental Microbiology 11, 1658-1671.

Jiang, Y., Jin, C., Sun, B., 2014. Soil aggregate stratification of nematodes and ammonia oxidizers affects nitrification in an acid soil. Environmental Microbiology 16, 3083-3094.

Jin, V.L., Evans, R.D., 2007. Elevated $\mathrm{CO}_{2}$ increases microbial carbon substrate use and nitrogen cycling in Mojave Desert soils. Global Change Biology 13, 452-465.

Karhu, K., Auffret, M.D., Dungait, J.A., Hopkins, D.W., Prosser, J.I., Singh, B.K., Subke, J.A., Wookey, P.A., Agren, G.I., Sebastia, M.T., Gouriveau, F., Bergkvist, G., Meir, P., Nottingham, A.T., Salinas, N., Hartley, I.P., 2014. Temperature sensitivity of soil respiration rates enhanced by microbial community response. Nature 513, 81-84.

Ke, X., Angel, R., Lu, Y., Conrad, R., 2013. Niche differentiation of ammonia oxidizers and nitrite oxidizers in rice paddy soil. Environmental Microbiology 15, 2275-2292.

Kembel, S.W., 2009. Disentangling niche and neutral influences on community assembly: assessing the performance of community phylogenetic structure tests. Ecology Letters 12, 949-960.

Kembel, S.W., Cowan, P.D., Helmus, M.R., Cornwell, W.K., Morlon, H., Ackerly, D.D., Blomberg, S.P., Webb, C.O., 2010. Picante: R tools for integrating phylogenies and ecology. Bioinformatics (Oxford, England) 26, 1463-1464.

Kim, H.Y., Lieffering, M., Kobayashi, K., Okada, M., Miura, S., 2003. Seasonal changes in the effects of elevated $\mathrm{CO}_{2}$ on rice at three levels of nitrogen supply: a free air $\mathrm{CO}_{2}$ enrichment (FACE) experiment. Global Change Biology 9, 826-837.
Kimball, B., Kobayashi, K., Bindi, M., (2002). Responses of agricultural crops to free-air $\mathrm{CO} 2$ enrichment. Advances in Agronomy 77, 293-368.

Kimura, M., 2000. Anaerobic microbiology in waterlogged rice fields. Soil Biochemistry 10, 35-138.

Kögel-Knabner, I., Amelung, W., Cao, Z., Fiedler, S., Frenzel, P., Jahn, R., Kalbitz, K., Kölbl, A., Schloter, M., 2010. Biogeochemistry of paddy soils. Geoderma 157, 1-14.

Krepski, S.T., Hanson, T.E., Chan, C.S., 2012. Isolation and characterization of a novel biomineral stalk-forming iron-oxidizing bacterium from a circumneutral groundwater seep. Environmental Microbiology 14, 1671-1680.

Kusian, B., Bowien, B., 1997. Organization and regulation of $\mathrm{cbb} \mathrm{CO}_{2}$ assimilation genes in autotrophic bacteria. FEMS Microbiology Reviews 21, 135-155.

Kuzyakov, Y., Domanski, G., 2000. Carbon input by plants into the soil. Journal of Plant Nutrition and Soil Science 163, 421-431.

Lal, R., 2008. Sequestration of atmospheric $\mathrm{CO}_{2}$ in global carbon pools. Energy \& Environmental Science 1, 86-100.

Lange, M., Eisenhauer, N., Sierra, C.A., Bessler, H., Engels, C., Griffiths, R.I., Mellado-Vázquez, P.G., Malik, A.A., Roy, J., Scheu, S., Steinbeiss, S., Thomson, B.C., Trumbore, S.E., Gleixner, G., 2015. Plant diversity increases soil microbial activity and soil carbon storage. Nature Communications 6, 6707.

Lennon, J.T., Jones, S.E., 2011. Microbial seed banks: the ecological and evolutionary implications of dormancy. Nature Reviews. Microbiology 9, 119-130.

Liesack, W., Schnell, S., Revsbech, N.P., 2000. Microbiology of flooded rice paddies. FEMS Microbiology Reviews 24, 625-645.

Liu, Y., Li, M., Zheng, J., Li, L., Zhang, X., Zheng, J., Pan, G., Yu, X., Wang, J., 2014. Short-term responses of microbial community and functioning to experimental $\mathrm{CO}_{2}$ enrichment and warming in a Chinese paddy field. Soil Biology \& Biochemistry 77, 58-68.

Long, X.E., Yao, H., Wang, J., Huang, Y., Singh, B.K., Zhu, Y.G., 2015. Community structure and soil $\mathrm{pH}$ determine chemoautotrophic carbon dioxide fixation in drained paddy soils. Environmental Science \& Technology 49, 7152-7160.

Luo, Y., 2007. Terrestrial carbon-cycle feedback to climate warming. Annual Review of Ecology, Evolution, and Systematics 38, 683712.

McMurdie, P.J., Holmes, S., 2014. Waste not, want not: why rarefying microbiome data is inadmissible. PLoS Computational Biology 10 , e1003531.

Miltner, A., Kopinke, F.D., Kindler, R., Selesi, D., Hartmann, A., Kästner, M., 2005. Non-phototrophic $\mathrm{CO}_{2}$ fixation by soil microorganisms. Plant and Soil 269, 193-203.

Nie, M., Pendall, E., Bell, C., Gasch, C.K., Raut, S., Tamang, S., Wallenstein, M.D., 2013. Positive climate feedbacks of soil microbial communities in a semi-arid grassland. Ecology Letters 16, 234-241.

Olk, D., Senesi, N., 2000. Properties of chemically Extracted Soil Organic Matter in Intensively Cropped Lowland Rice Soils. In: Kirk, G.J.D., Olk, D.C. eds. Carbon and Nitrogen Dynamics in Flooded Soils. Makati City (Philippines): International Rice Research Institute, 65-87.

Ortiz, M., Legatzki, A., Neilson, J.W., Fryslie, B., Nelson, W.M., Wing, 
R.A., Soderlund, C.A., Pryor, B.M., Maier, R.M., 2014. Making a living while starving in the dark: metagenomic insights into the energy dynamics of a carbonate cave. ISME Journal 8, 478491.

Ouyang, Y., Norton, J.M., Stark, J.M., Reeve, J.R., Habteselassie, M. Y., 2016. Ammonia-oxidizing bacteria are more responsive than archaea to nitrogen source in an agricultural soil. Soil Biology \& Biochemistry 96, 4-15.

Pan, G.X., Li, L.Q., Wu, L.S., Zhang, X.H., 2004. Storage and sequestration potential of topsoil organic carbon in China's paddy soils. Global Change Biology 10, 79-92.

Pausch, J., Kuzyakov, Y., 2018. Carbon input by roots into the soil: Quantification of rhizodeposition from root to ecosystem scale. Global Change Biology 24, 1-12.

Pepe-Ranney, C., Campbell, A.N., Koechli, C.N., Berthrong, S., Buckley, D.H., 2016. Unearthing the ecology of soil microorganisms using a high resolution DNA-SIP approach to explore cellulose and xylose metabolism in soil. Frontiers in Microbiology 7, 703.

Piao, S., Fang, J., Ciais, P., Peylin, P., Huang, Y., Sitch, S., Wang, T., 2009. The carbon balance of terrestrial ecosystems in China. Nature 458, 1009-1013.

Pratscher, J., Dumont, M.G., Conrad, R., 2011. Ammonia oxidation coupled to $\mathrm{CO}_{2}$ fixation by archaea and bacteria in an agricultural soil. Proceedings of the National Academy of Sciences of the United States of America 108, 4170-4175.

Pritchard, S.G., 2011. Soil organisms and global climate change. Plant Pathology 60, 82-99.

Prober, S.M., Leff, J.W., Bates, S.T., Borer, E.T., Firn, J., Harpole, W. S., Lind, E.M., Seabloom, E.W., Adler, P.B., Bakker, J.D., Cleland, E.E., DeCrappeo, N.M., DeLorenze, E., Hagenah, N., Hautier, Y., Hofmockel, K.S., Kirkman, K.P., Knops, J.M.H., La Pierre, K.J., MacDougall, A.S., McCulley, R.L., Mitchell, C.E., Risch, A.C., Schuetz, M., Stevens, C.J., Williams, R.J., Fierer, N., 2015. Plant diversity predicts beta but not alpha diversity of soil microbes across grasslands worldwide. Ecology Letters 18, 85-95.

Radajewski, S., Ineson, P., Parekh, N.R., Murrell, J.C., 2000. Stableisotope probing as a tool in microbial ecology. Nature 403, 646649.

Razavi, B.S., Liu, S., Kuzyakov, Y., 2017. Hot experience for coldadapted microorganisms: temperature sensitivity of soil enzymes. Soil Biology \& Biochemistry 105, 236-243.

Rosenzweig, C., Casassa, G., Karoly, D.J., Imeson, A., Liu, C., Menzel, A., Rawlins, S., Root, T.L., Seguin, B., Tryjanowski, P., 2007. Assessment of observed changes and responses in natural and managed systems. Climatic Change 2007, 79.

Sahrawat, K.L., 2004. Organic matter accumulation in submerged soils. Advances in Agronomy 81, 170-203.

Saks, Ü., Davison, J., Öpik, M., Vasar, M., Moora, M., Zobel, M., 2013. Root-colonizing and soil-borne communities of arbuscular mycorrhizal fungi in a temperate forest understorey. Botany 92, 277-285.

Shen, J.P., Zhang, L.M., Zhu, Y.G., Zhang, J.B., He, J.Z., 2008. Abundance and composition of ammonia-oxidizing bacteria and ammonia-oxidizing archaea communities of an alkaline sandy loam. Environmental Microbiology 10, 1601-1611.

Shi, D.H., You, Z.L., Xu, C., Zhang, Q., Zhu, H.L., 2007. Synthesis, crystal structure and urease inhibitory activities of Schiff base metal complexes. Inorganic Chemistry Communications 10, 404 406.

Singh, B.K., Bardgett, R.D., Smith, P., Reay, D.S., 2010. Microorganisms and climate change: terrestrial feedbacks and mitigation options. Nature Reviews. Microbiology 8, 779-790.

Steven, B., Gallegos-Graves, L.V., Yeager, C., Belnap, J., Kuske, C. R., 2014. Common and distinguishing features of the bacterial and fungal communities in biological soil crusts and shrub root zone soils. Soil Biology \& Biochemistry 69, 302-312.

Stocker, T., Qin, D., Plattner, G., Tignor, M., Allen, S., Boschung, J., Nauels, A., Xia, Y., Bex, V., Midgley, P., (2013) IPCC, 2013: Climate Change 2013: The Physical Science Basis. Contribution of Working Group I to the Fifth Assessment Report of the Intergovernmental Panel on Climate Change. Cambridge Univ. Press, Cambridge, UK, and New York. p.1535.

Sun, Y., Huang, S., Yu, X., Zhang, W., 2015. Differences in fertilization impacts on organic carbon content and stability in a paddy and an upland soil in subtropical China. Plant and Soil 397, 189-200.

Tabita, F.R., Hanson, T.E., Li, H.Y., Satagopan, S., Singh, J., Chan, S., 2007. Function, structure, and evolution of the RubisCO-like proteins and their RubisCO homologs. Microbiology and Molecular Biology Reviews 71, 576-599.

Tourna, M., Freitag, T.E., Prosser, J.I., 2010. Stable isotope probing analysis of interactions between ammonia oxidizers. Applied and Environmental Microbiology 76, 2468-2477.

Trumbore, S.E., 1997. Potential responses of soil organic carbon to global environmental change. Proceedings of the National Academy of Sciences of the United States of America 94, 8284 8291.

Vuillemin, A., Wankel, S.D., Coskun, Ö.K., Magritsch, T., Vargas, S., Estes, E.R., Spivack, A.J., Smith, D.C., Pockalny, R., Murray, R. W., D'Hondt, S., Orsi, W.D., 2019. Archaea dominate oxic subseafloor communities over multimillion-year time scales. Science Advances 5, eaaw4108.

Wang, B., Zhao, J., Guo, Z., Ma, J., Xu, H., Jia, Z., 2015. Differential contributions of ammonia oxidizers and nitrite oxidizers to nitrification in four paddy soils. ISME Journal 9, 1062-1075.

Wang, J., Liu, X., Zhang, X., Smith, P., Li, L., Filley, T.R., Cheng, K., Shen, M., He, Y., Pan, G., 2016. Size and variability of crop productivity both impacted by $\mathrm{CO}_{2}$ enrichment and warming-a case study of 4 year field experiment in a Chinese paddy. Agriculture, Ecosystems \& Environment 221, 40-49.

Webb, C.O., Ackerly, D.D., McPeek, M.A., Donoghue, M.J., 2002. Phylogenies and community ecology. Annual Review of Ecology and Systematics 33, 475-505.

Wetzel, F.T., Kissling, W.D., Beissmann, H., Penn, D.J., 2012. Future climate change driven sea-level rise: secondary consequences from human displacement for island biodiversity. Global Change Biology 18, 2707-2719.

Xiong, J., Sun, H., Peng, F., Zhang, H., Xue, X., Gibbons, S.M., Gilbert, J.A., Chu, H., 2014. Characterizing changes in soil bacterial community structure in response to short-term warming. FEMS Microbiology Ecology 89, 281-292.

Yuan, H., Ge, T., Chen, C., O'Donnell, A.G., Wu, J., 2012. Significant role for microbial autotrophy in the sequestration of soil carbon. 
Applied and Environmental Microbiology 78, 2328-2336

Zhou, J., Xue, K., Xie, J., Deng, Y., Wu, L., Cheng, X., Fei, S., Deng, S., He, Z., Van Nostrand, J.D., Luo, Y., 2012. Microbial mediation of carbon-cycle feedbacks to climate warming. Nature Climate Change 2, 106-110.
Zhu, C., Ling, N., Guo, J.J., Wang, M., Guo, S.W., Shen, C.R., 2016. Impacts of fertilization regimes on arbuscular mycorrhizal fungal (AMF) community composition were correlated with organic matter composition in maize rhizosphere soil. Frontiers in Microbiology 7 , 7. 